\title{
Five New Legionella Species Isolated from Water
}

\author{
P. JULIAN DENNIS, ${ }^{1} \dagger$ DON J. BRENNER, ${ }^{2}$ W. LANIER THACKER,${ }^{3}$ ROBIN WAIT, ${ }^{1 *}$ \\ GRAHAM VESEY,${ }^{1} \dagger$ ARNOLD G. STEIGERWALT,${ }^{2}$ \\ AND ROBERT F. BENSON ${ }^{3}$
}

Division of Pathology, Public Health Laboratory Service, Centre for Applied Microbiology and Research, Porton Down, Salisbury, Wiltshire SP4 OJG, United Kingdom, ${ }^{1}$ and Meningitis and Special Pathogens Branch ${ }^{2}$ and Respiratory Diseases Branch, ${ }^{3}$ Division of Bacterial and Mycotic Diseases, National Center for Infectious Diseases, Centers for Disease Control, Atlanta, Georgia 30333

\begin{abstract}
Fourteen Legionella-like strains isolated from aquatic sources have been characterized serologically, biochemically, and in terms of DNA relatedness. The strains grew on buffered charcoal-yeast extract agar but not on blood agar and displayed phenotypic characteristics typical of the family Legionellaceae, including a requirement for cysteine, cellular fatty acid compositions in which branched-chain acids predominate, and the possession of isoprenoid quinones of the ubiquinone series with more than 10 isoprene units in their side chains. All were nonfermentative, lacked urease, were incapable of nitrate reduction, and reacted positively with a DNA probe specific for the Legionellaceae. DNA hybridization studies in which the hydroxyapatite method was used demonstrated that the strains represented five new species of the genus Legionella. Nine of the strains were more than $90 \%$ interrelated, and the name Legionella londiniensis sp. nov, is proposed for this group. Two strains formed a second hybridization group, for which the name Legionella nautarum sp. nov. is proposed, while the three remaining species, Legionella geestiana sp. nov., Legionella quateirensis sp. nov., and Legionella worsleiensis sp. nov., are each represented by a single strain. The levels of relatedness of the new species to each other are $23 \%$ or less, and the levels of relatedness to other members of the genus ranged from 0 to $36 \%$. $L$. geestiana, $L$. nautarum, and $L$. londiniensis are serologically unrelated to all other known Legionella species. L. worsleiensis cannot be separated from Legionella pneumophila serogroup 4 by serological methods and is also serologically indistinguishable from $L$. quateirensis; distinctions may be made on the basis of fatty acid composition and biochemical reactions.
\end{abstract}

It has now been 14 years since the classification of Legionella pneumophila as a new bacterium in the family Legionellaceae (11). Since this classification an additional 34 species of this genus have been described $(1-3,7,10,27-30$, $32,39,40)$.

Between 1982 and 1984 the Public Health Laboratory Service in England and Wales undertook a survey of buildings, particularly hotels and hospitals, to determine the incidence of legionellae in their water systems and to identify the physical and chemical factors predisposing buildings to colonization. During this survey a number of strains were isolated that conformed to the definition of the family Legionellaceae but could not be assigned to previously described species. In this paper we describe the characterization of these strains and propose names for five new species isolated from water samples. To our knowledge none of these species has so far been implicated in human infections.

\section{MATERIALS AND METHODS}

Bacterial strains. Strains of the five new species are listed in Table 1. All strains were isolated by direct plating onto buffered charcoal-yeast extract (BCYE) media made selective by addition of glycine and antibiotics, using a standardized isolation protocol (13). Briefly, water samples were concentrated by membrane filtration, and the material re-

\footnotetext{
* Corresponding author.

$\uparrow$ Present address: Thames Water Utilities, Environment and Science, Spencer House Laboratory, Reading, Berkshire RG2 0JN, United Kingdom.
}

tained on each filter was resuspended in water and directly plated onto the selective media. Portions of the concentrates were also treated with an acid buffer (6) or heated to $50^{\circ} \mathrm{C}$ prior to plating (13). Strains were cultured and maintained on BCYE agar at $35 \pm 1^{\circ} \mathrm{C}$ in air containing $2.5 \% \mathrm{CO}_{2}$. Suspensions were stored at $-80^{\circ} \mathrm{C}$.

Cultural and biochemical tests. All strains of the new species were tested by the methods described by Vesey et al. (33). These methods consist of modifications of procedures previously described for the differentiation of members of the Legionellaceae, together with some additional tests. All of the strains were stained by using the Preston-Morrell modification of Gram stain (24). The requirement for L-cysteine was investigated by plating cultures onto BCYE agar lacking this amino acid. Cellular fluorescence and pigment production on media supplemented with aromatic substrates were investigated by using modified versions of the methods described by Vickers and Yu (35). The bromocresol purple spot test was performed as described by Garrity et al. (15). Dye-containing media were prepared as described by Holmes (17) and Vickers et al. (34).

The following enzyme activities were tested for: elastase production, casein hydrolysis, albumin degradation, chondroitin sulfate degradation, starch hydrolysis, DNase activity, gelatin hydrolysis, lipase activity, and protease activity. Hydrolysis of sodium hippurate was tested by the method of Hébert (16). Combined peroxidase and catalase activities were measured by a modification of the procedure of Pine et al. (23). Esterase and alkaline phosphatase activities were determined by the methods described by Orrison et al. (22). $\beta$-Lactamase production was measured by using a chromogenic test with nitrocefin-impregnated discs (Beckton, Dick- 
TABLE 1. Bacterial strain information

\begin{tabular}{|c|c|c|c|}
\hline Strain & Source & Location & $\begin{array}{l}\mathrm{G}+\mathrm{C} \text { content } \\
\quad(\mathrm{mol} \%)\end{array}$ \\
\hline L. geestiana $1308^{\mathrm{T}}\left(=\text { ATCC } 49504^{\mathrm{T}}\right)^{a}$ & Domestic hot water tap & Geest Office Building, London, United Kingdom & 52 \\
\hline L. nautarum $1224^{\mathrm{T}}\left(=\right.$ ATCC $\left.49506^{\mathrm{T}}\right)$ & Domestic hot water tap & $\begin{array}{l}\text { Seamans Hospital, Greenwich, London, United } \\
\text { Kingdom }\end{array}$ & 41 \\
\hline L. nautarum 1231 & Domestic hot water tap & $\begin{array}{l}\text { Seamans Hospital, Greenwich, London, United } \\
\text { Kingdom }\end{array}$ & \\
\hline L. londiniensis $1477^{\mathrm{T}}\left(=\operatorname{ATCC} 49505^{\mathrm{T}}\right)$ & Cooling tower pond water & Office building, London, United Kingdom & 43 \\
\hline L. londiniensis 1466 & Cooling tower pond water & Office building, London, United Kingdom & \\
\hline L. londiniensis 1468 & Cooling tower pond water & Office building, London, United Kingdom & \\
\hline L. londiniensis 1471 & Cooling tower pond water & Office building, London, United Kingdom & \\
\hline L. londiniensis 1472 & Cooling tower pond water & Office building, London, United Kingdom & \\
\hline L. londiniensis 1473 & Cooling tower pond water & Office building, London, United Kingdom & \\
\hline L. londiniensis 1474 & Cooling tower pond water & Office building, London, United Kingdom & \\
\hline L. londiniensis 1475 & Cooling tower pond water & Office building, London, United Kingdom & \\
\hline L. londiniensis 1476 & Cooling tower pond water & Office building, London, United Kingdom & \\
\hline L. quateirensis $1335^{\mathrm{T}}\left(=\operatorname{ATCC} 49507^{\mathrm{T}}\right)$ & Shower in bathroom & Hotel, Quarteira, Portugal & 39 \\
\hline L. worsleiensis $1347^{\mathrm{T}}\left(=\right.$ ATCC $\left.49508^{\mathrm{T}}\right)$ & Cooling tower return flow & Industrial site, Worsley, United Kingdom & 41 \\
\hline
\end{tabular}

${ }^{a}$ ATCC, American Type Culture Collection.

inson and Co., Oxford, United Kingdom) which were moistened and wiped across a single colony. The oxidase test was performed by using a $0.5 \%$ suspension of tetramethyl $p$-phenylenediamine. Motility was determined by examining wet mounts of cultures grown in yeast broth (25) for 2,3 , and 4 days, using phase-contrast microscopy. Growth (if present) on Mueller-Hinton agar (38) and Legionella blood agar (14) was noted after 7 days of incubation at $35 \pm 1^{\circ} \mathrm{C}$ in the presence of $2.5 \% \mathrm{CO}_{2}$.

SAT. Strains $1224^{\mathrm{T}}\left(\mathrm{T}=\right.$ type strain) $1308^{\mathrm{T}}, 1335^{\mathrm{T}}, 1347^{\mathrm{T}}$, and $1477^{\mathrm{T}}$ were used to prepare slide agglutination test (SAT) antigens and antisera (31). The five antisera were tested against reference strains of previously described legionellae ( 34 species and 53 serogroups) and against all of the strains listed in Table 1. Similarly, antigens prepared from these five strains were tested with antisera to all of the strains listed in Table 1. Antigens and antisera for two recently described Legionella serogroups, Legionella quinlivanii serogroup 2 and Legionella erythra serogroup 2 (4, 26), were not available for testing.

Extraction and analysis of cellular fatty acids. Strains were grown on BCYE media for 3 days at $35 \pm 1^{\circ} \mathrm{C}$ in air containing $2.5 \% \mathrm{CO}_{2}$, harvested into distilled water, and freeze dried. Fatty acid methyl esters were prepared by acid methanolysis of the freeze-dried cells as previously described (36). Gas-liquid chromatography was performed with a Carlo-Erba model 4130 chromatograph fitted with a fusedsilica BP-5 column ( $25 \mathrm{~m}$ by $0.2 \mathrm{~mm}$; SGE Limited, Milton Keynes, United Kingdom). Helium was used as the carrier gas at a linear velocity of $30 \mathrm{~cm} \mathrm{~s}^{-1}$. The samples (dissolved in trimethylpentane) were introduced by splitless injection (splitless time, $30 \mathrm{~s}$ ) at an initial oven temperature of $80^{\circ} \mathrm{C}$. After a 1-min delay the oven was programmed to increase its temperature to $210^{\circ} \mathrm{C}$ at a rate of $40^{\circ} \mathrm{C} \mathrm{min}-1$, and this temperature was held for $20 \mathrm{~min}$. Peaks were identified by their relative retention times and by gas chromatographymass spectrometry, using a model MS80 RFA mass spectrometer (Kratos Ltd., Manchester, United Kingdom) interfaced with a Carlo-Erba model 5160 chromatograph. The chromatographic conditions were the same as those described above, except that a BP-1 column ( $25 \mathrm{~m}$ by $0.2 \mathrm{~mm})$ was used. The instrument was operated in electron impact mode at an ionization energy of $70 \mathrm{e} \mathrm{V}$, a trap current of 100 $\mu \mathrm{A}$, and a scan rate of $0.3 \mathrm{~s}$ per decade of mass.

Extraction and analysis of isoprenoid quinones. Isoprenoid quinones were extracted by the method of Collins et al. (12). Between 20 and $50 \mathrm{mg}$ of freeze-dried cells was suspended in $20 \mathrm{ml}$ of chloroform-methanol (2:1) and magnetically stirred for $2 \mathrm{~h}$ at room temperature. The mixture was filtered (Whatman no. 1 filter paper), and the filtrate was dried by rotary evaporation and purified by thin-layer chromatography on silica gel $60 \mathrm{~F}_{254}$ plates (BDH Ltd., Poole, United Kingdom). The plates were developed with hexane-diethyl ether (85:15), and the quinone-containing band was visualized under UV light $(254 \mathrm{~nm})$ and scraped off. Quinones were eluted from the silica with $5 \mathrm{ml}$ of chloroform and filtered through a sintered glass funnel, and the chloroform was evaporated in a stream of nitrogen. The purified quinones were analyzed by reversed-phase thin-layer chromatography, high-performance liquid chromatography (HPLC), and mass spectrometry.

Reverse-phase high-performance thin-layer chromatography (RP-HPTLC) was performed by using HPTLC $18 \mathrm{~F}_{254}$ plates (10 by $10 \mathrm{~cm} ; \mathrm{BDH})$ developed in acetone-acetonitrile $(80: 20)$. The separated quinones were visualized by viewing the developed plates under UV light $(254 \mathrm{~nm})$. The HPLC system consisted of two model 510 pumps, an automatic gradient controller, a model 710B (Waters) intelligent sample processor (WISP), a model 481 LC spectrophotometer, and a model 740 data module (all obtained from Waters Associates). The column was a $\mu$ Bondapak $C_{18}$ radial compression cartridge, used in conjunction with a model RCM 100 radial compression module. The mobile phase was methanol-1chlorobutane $(70: 30)$ at a flow rate of $1.5 \mathrm{ml} \mathrm{min}^{-1}$. The quinone samples were dissolved in $200 \mu \mathrm{l}$ of 1-chlorobutane, and the WISP was programmed to inject $15 \mu 1$. The eluted quinones were detected by their UV absorption at $270 \mathrm{~nm}$.

Negative-ion fast atom bombardment mass spectra were recorded with a model MS80 RFA mass spectrometer (Kratos) equipped with a model BN11F saddle field gun (Ion Tech Ltd., Teddington, United Kingdom) using xenon as the bombarding gas. The accelerating voltage was $4 \mathrm{k} \mathrm{V}$, and the magnet was scanned at $30 \mathrm{~s}$ decade ${ }^{-1}$ from a starting mass of 1,600 . Quinone samples ( 1 to $10 \mu \mathrm{g}$ ) in $1 \mu \mathrm{l}$ of chloroform 
TABLE 2. DNA relatedness of the new Legionella species

\begin{tabular}{|c|c|c|c|c|c|c|c|c|c|}
\hline \multirow{3}{*}{$\begin{array}{l}\text { Source of labelled or } \\
\text { unlabelled DNA }\end{array}$} & \multicolumn{9}{|c|}{ DNA relatedness to labelled or unlabelled DNA from: } \\
\hline & \multicolumn{3}{|c|}{ L. nautarum $1224^{\mathbf{T}}$} & \multirow{2}{*}{$\begin{array}{l}\text { L. geestiana } \\
1308^{\mathrm{T}}: \% \\
\text { relatedness } \\
\text { at } 60^{\circ} \mathrm{C}\end{array}$} & \multirow{2}{*}{$\begin{array}{l}\text { L. quateirensis } \\
1335^{\mathrm{T}}: \% \text { relat- } \\
\text { edness at } 60^{\circ} \mathrm{C}\end{array}$} & \multirow{2}{*}{$\begin{array}{l}\text { L. worsleiensis } \\
1347^{\mathrm{T}}: \% \text { relat- } \\
\text { edness at } 60^{\circ} \mathrm{C}\end{array}$} & \multicolumn{3}{|c|}{ L. londiniensis $1477^{\mathrm{T}}$} \\
\hline & $\begin{array}{c}\text { \% Related- } \\
\text { ness at } \\
60^{\circ} \mathrm{C}\end{array}$ & $\begin{array}{l}\text { Diver- } \\
\text { gence }\end{array}$ & $\begin{array}{c}\text { \% Related- } \\
\text { ness at } \\
75^{\circ} \mathrm{C}\end{array}$ & & & & $\begin{array}{c}\% \text { Related- } \\
\text { ness at } \\
60^{\circ} \mathrm{C}\end{array}$ & $\begin{array}{l}\text { Diver- } \\
\text { gence }\end{array}$ & $\begin{array}{c}\% \text { Related- } \\
\text { ness at } \\
75^{\circ} \mathrm{C}\end{array}$ \\
\hline L. nautarum $1224^{T}$ & 100 & 0.0 & 100 & & 6 & & & & \\
\hline L. nautarum 1231 & 70 & 0.0 & 78 & & & & & & \\
\hline L. geestiana $1308^{\mathrm{T}}$ & 4 & & & 100 & 11 & 3 & & & \\
\hline L. quateirensis $1335^{\mathrm{T}}$ & 2 & & & 6 & 100 & 13 & & & \\
\hline L. worsleiensis $1347^{\mathrm{T}}$ & 4 & & & 11 & 23 & 100 & 3 & & \\
\hline L. londiniensis $1477^{\mathrm{T}}$ & 2 & & & 3 & 6 & 4 & 100 & 0.0 & 100 \\
\hline L. londiniensis 1466 & & & & & & & 94 & 1.0 & 100 \\
\hline L. londiniensis 1468 & & & & & & & 99 & 0.0 & 99 \\
\hline L. londiniensis 1471 & & & & & & & 98 & 0.0 & 87 \\
\hline L. londiniensis 1472 & & & & & & & 97 & 0.5 & 100 \\
\hline L. londiniensis 1473 & & & & & & & 100 & 0.0 & 100 \\
\hline L. londiniensis 1474 & & & & & & & 94 & 0.0 & 97 \\
\hline L. londiniensis 1475 & & & & & & & 98 & 0.5 & 98 \\
\hline L. londiniensis 1476 & & & & & & & 95 & 0.5 & 95 \\
\hline L. pneumophila Philadelphia $1^{\mathrm{T}}$ & 7 & & & 2 & 12 & 6 & 4 & & \\
\hline L. bozemanii $\mathrm{WIGA}^{\mathrm{T}}$ & 6 & & & 3 & 8 & 4 & 4 & & \\
\hline L. micdadei TATLOCK ${ }^{\mathrm{T}}$ & 24 & & & 1 & 8 & 8 & 0 & & \\
\hline L. dumoffii $\mathrm{NY}-23^{\mathrm{T}}$ & 9 & & & 4 & 13 & 4 & 3 & & \\
\hline L. gormanii LS-13 ${ }^{\mathrm{T}}$ & 19 & & & 5 & 12 & 4 & 0 & & \\
\hline L. longbeachae Long Beach $4^{\mathrm{T}}$ & 9 & & & 4 & 10 & 2 & 7 & & \\
\hline L. jordanis $\mathrm{BL}-540^{\mathrm{T}}$ & 8 & & & 6 & 2 & 5 & 3 & & \\
\hline L. oakridgensis Oak Ridge $10^{\mathrm{T}}$ & 5 & & & 3 & 5 & 2 & 12 & & \\
\hline L. wadsworthii $81-716 \mathrm{~A}^{\mathrm{T}}$ & 9 & & & 6 & 11 & 3 & 8 & & \\
\hline L. feeleii WO-44C-C3 ${ }^{\mathrm{T}}$ & 14 & & & 3 & 7 & 2 & 5 & & \\
\hline L. sainthelensi Mount Saint Helens $4^{\mathrm{T}}$ & 6 & & & 4 & 7 & 2 & 3 & & \\
\hline L. anisa WA-316-C3 ${ }^{\mathrm{T}}$ & 4 & & & & & 6 & & & \\
\hline L. maceachernii PX-1-G2-E2 ${ }^{\mathrm{T}}$ & 9 & & & 5 & 9 & 2 & 0 & & \\
\hline L. jamestowniensis JA-26-G1-E2 ${ }^{\mathrm{T}}$ & 11 & & & 4 & 8 & 2 & 5 & & \\
\hline L. rubrilucens WA- $270 \mathrm{~A}-\mathrm{C} 2^{\mathrm{T}}$ & 1 & & & 6 & & 3 & 6 & & \\
\hline L. erythra $\mathrm{SE}-32 \mathrm{~A}-\mathrm{C} 8^{\mathrm{T}}$ & 9 & & & 10 & 10 & 6 & 9 & & \\
\hline L. hackeliae Lansing $2^{\mathrm{T}}$ & 11 & & & 4 & 7 & 6 & 8 & & \\
\hline L. spiritensis Mount Saint Helens $9^{\mathrm{T}}$ & 8 & & & 6 & 9 & 1 & 6 & & \\
\hline L. parisiensis $\mathrm{PF}-209 \mathrm{C}-\mathrm{C} 2^{\mathrm{T}}$ & 10 & & & 2 & 11 & 5 & 2 & & \\
\hline L. cherrii $\mathrm{ORW}^{\mathrm{T}}$ & 2 & & & & & 2 & & & \\
\hline L. steigenwaltii $\mathrm{SC}-18-\mathrm{C} 9^{\mathrm{T}}$ & 0 & & & & & 3 & & & \\
\hline L. santicrucis $\mathrm{SC}-63-\mathrm{C} 7^{\mathrm{T}}$ & 2 & & & & & 2 & & & \\
\hline L. israelensis Bercovier $4^{\mathrm{T}}$ & 4 & & & 4 & 5 & 3 & 8 & & \\
\hline L. birminghamensis $1407-\mathrm{AL}-\mathrm{H}^{\mathrm{T} b}$ & 1 & & & 2 & 2 & 1 & 2 & & \\
\hline L. cincinnatiensis $72-\mathrm{OH}-\mathrm{H}^{\mathrm{T} b}$ & 2 & & & 3 & 4 & 3 & 1 & & \\
\hline L. brunensis $441-1^{\mathrm{Tb}}$ & 3 & & & 0 & 2 & 2 & 1 & & \\
\hline L. moravica $316-36^{\mathrm{Tb}}$ & 2 & & & 3 & 36 & 24 & 1 & & \\
\hline L. quinlivanii 1441-AUS-E $\mathrm{E}^{\mathrm{T} b}$ & 2 & & & 1 & 4 & 2 & 2 & & \\
\hline L. tucsonensis $1087-\mathrm{AZ}-\mathrm{H}^{\mathrm{T} b}$ & 10 & & & 6 & 11 & 12 & 3 & & \\
\hline L. gratiana Lyon $8420412^{\mathrm{T} b}$ & 3 & & & 4 & 8 & 6 & 3 & & \\
\hline L. faiffieldensis $1725-\mathrm{AUS}-\mathrm{E}^{\mathrm{T} b}$ & 9 & & & 1 & 10 & 8 & 5 & & \\
\hline L. adelaidensis $1762-\mathrm{AUS}-\mathrm{E}^{\mathrm{Th}}$ & 2 & & & 3 & 3 & 1 & 2 & & \\
\hline L. shakespearei $214^{\mathrm{Tb}}$ & 3 & & & 2 & 9 & 7 & 3 & & \\
\hline L. lansingensis $1677-\mathrm{MI}-\mathrm{H}^{\mathrm{T} b}$ & 2 & & & 1 & 2 & 2 & 1 & & \\
\hline
\end{tabular}

a Source of unlabelled DNA except as noted below.

${ }^{b}$ Source of labelled DNA.

were mixed with $1 \mu \mathrm{l}$ of 3 -nitrobenzyl alcohol matrix on the stainless steel fast atom bombardment target. Between 5 and 10 scans were acquired and averaged by using the raw data facilities of a model DS90 data system. Cesium iodide was used as the mass calibrant.

DNA studies. The guanine-plus-cytosine $(\mathrm{G}+\mathrm{C})$ content of DNA was determined with a spectrophotometer by thermal denaturation (20). Preparation of DNA and use of the hydroxyapatite method for DNA hybridization have been described previously (9). In vitro labelling of DNA was performed enzymatically by using $\left[{ }^{32} \mathrm{P}\right] \mathrm{dCTP}$ provided in a nick translation reagent kit (catalog no. $810608 \mathrm{~B}$; Bethesda Research Laboratories, Inc., Gaithersburg, Md.), as directed by the manufacturer. Percentages of divergence in related DNA sequences were determined to the nearest $0.5 \%$ by thermal elution of DNA from hydroxyapatite, on the assumption that each degree of diminished thermal stability in a heteroduplex, compared with the stability of a homolo- 
gous DNA duplex, was caused by $1 \%$ unpaired bases (9). A ${ }^{3} \mathrm{H}$-labelled Legionella-specific DNA probe (18) was used under standard hybridization conditions. The probe was a gift from D. E. Kohne (Gen-Probe Inc., San Diego, Calif.).

\section{RESULTS}

Putative Legionella isolates from the environmental sampling study were investigated by using routine biochemical and serological tests. A total of 17 strains could not be identified. DNA hybridization studies subsequently showed that one of these strains was a Legionella pneumophila strain and two others were strains of the newly described species Legionella rubrilucens (10).

DNA hybridization. The 14 remaining strains were tested to determine their levels of DNA relatedness to each other and to known Legionella species (Table 2). In some cases the new strains were not tested against Legionella anisa, $L$. rubrilucens, Legionella cherrii, Legionella steigerwaltii, and Legionella santicrucis, since each of these species is substantially related to one or more of the other species (10) against which the new strains were tested.

The new strains formed five hybridization groups, which were 0 to $36 \%$ related to known Legionella species. The reference strain from each group hybridized with a $L e$ gionella-specific DNA probe (data not shown). Strain $1477^{\mathrm{T}}$ and eight other strains were more than $90 \%$ related; the name Legionella londiniensis sp. nov. is proposed for these organisms. Strains $1224^{\mathrm{T}}$ and 1231 formed a second hybridization group, for which the name Legionella nautarum sp. nov. is proposed. Each of the three remaining strains comprised a separate hybridization group. The name Legionella geestiana sp. nov. is proposed for strain $1308^{\mathrm{T}}$, the name Legionella quateirensis sp. nov. is proposed for strain $1335^{\mathrm{T}}$, and the name Legionella worsleiensis sp. nov. is proposed for strain $1347^{\mathrm{T}}$.

SAT. No cross-reactions were observed with antigens of the two strains of $L$. nautarum and the nine $L$. londiniensis strains when they were tested with antisera prepared against members of the previously described 34 species and 53 serogroups of the genus Legionella or with antisera prepared against $L$. geestiana $1308^{\mathrm{T}}, L$. quateirensis $1335^{\mathrm{T}}$, and $L$. worsleiensis $1347^{\mathrm{T}}$. The cross-reactions observed with $L$. geestiana, L. worsleiensis, and L. quateirensis antigens are listed in Table 3. Absorption of Legionella jamestowniensis antiserum with L. geestiana cells removed agglutinating antibodies against $L$. geestiana but not agglutinating antibodies against $L$. jamestowniensis. Two of the antisera which cross-reacted with $L$. worsleiensis cells, the $L$. pneumophila serogroup 4 strain Portland 1 and L. quateirensis antisera, could not be made serogroup specific. Absorption of these antisera with $L$. worsleiensis cells removed all agglutinating antibodies for both the heterologous and the homologous strains. L. quateirensis antigen also crossreacted with several Legionella antisera. However, these cross-reactions were removed by absorbing the antisera with L. quateirensis cells.

The results of testing antisera prepared against the five new species with homologous and heterologous SAT antigens are presented in Table 4. Antisera prepared against the type strains of $L$. nautarum, $L$. londiniensis, and $L$. geestiana were negative with all heterologous Legionella antigens. $L$. nautarum $1224^{\mathrm{T}}$ antiserum reacted $4+$ with both $L$. nautarum strains, and $L$. londiniensis $1477^{\mathrm{T}}$ antiserum reacted $4+$ with all nine $L$. londiniensis strains. Antiserum against $L$. worsleiensis $1347^{\mathrm{T}}$, at its optimal working dilution of $1: 16$, cross-reacted $4+$ with $L$. pneumophila serogroup 4 strain Portland 1 and $L$. quateirensis cells and $2+$ with $L$. pneumophila serogroup 8 strain Concord 3 cells. Absorption of $1347^{\mathrm{T}}$ antiserum with $1335^{\mathrm{T}}$ cells removed agglutinating antibodies to strain $1335^{\mathrm{T}}$ but not agglutinating antibodies to strain Portland 1. Further absorption of $1347^{\mathrm{T}}$ antiserum with Portland 1 cells removed all agglutinating antibodies to both strain Portland 1 and the homologous strain.

At its optimal working dilution of $1: 16, L$. quateirensis antiserum cross-reacted $4+$ with $L$. pneumophila serogroup 4 strain Los Angeles 1, L. pneumophila serogroup 10 strain Leiden 1, L. pneumophila serogroup 13 strain 82A3105, and $1347^{\mathrm{T}}$ cells, and its showed $2+$ and $1+$ agglutination with $L$. pneumophila serogroup 4 strain Portland 1 and serogroup 12 strain 570-CO-H, respectively. Absorption of L. quateirensis antiserum with L. pneumophila serogroup 13 strain $82 \mathrm{~A} 3105$ cells removed all heterologous agglutinating antibodies except the L. worsleiensis $1347^{\mathrm{T}}$ antibodies. Further absorption of the $1335^{\mathrm{T}}$ antiserum with $1347^{\mathrm{T}}$ cells removed all heterologous $\left(1347^{\mathrm{T}}\right)$ and homologous $\left(1335^{\mathrm{T}}\right)$ agglutinating activities.

Cellular fatty acid composition. The members of the $L e$ gionellaceae are characterized (unusually for gram-negative organisms) by the possession of high levels of branched-

TABLE 3. Cross-reactions observed with unabsorbed Legionella antisera in the SAT

\begin{tabular}{|c|c|c|c|c|}
\hline \multicolumn{3}{|c|}{ Legionella antigen } & \multirow{2}{*}{ Legionella antiserum (unabsorbed) } & \multirow{2}{*}{ Cross-reaction } \\
\hline Species & Serogroup & Strain & & \\
\hline L. geestiana & 1 & $1308^{\mathrm{T}}$ & L. jamestowniensis JA-26-G1-E2 ${ }^{\mathrm{T}}$ & $3+^{a}$ \\
\hline L. worsleiensis & 1 & $1347^{\mathrm{T}}$ & $\begin{array}{l}\text { L. pneumophila serogroup } 4 \text { strain Portland } 1 \\
\text { L. pneumophila serogroup } 5 \text { strain Dallas } 1 \\
\text { L. pneumophila serogroup } 8 \text { strain Concord } 3 \\
\text { L. pneumophila serogroup } 10 \text { strain Leiden } 1 \\
\text { L. quateirensis serogroup } 1 \text { strain } 1335^{\mathrm{T}}\end{array}$ & $\begin{array}{l}4+ \\
4+ \\
4+ \\
4+ \\
4+\end{array}$ \\
\hline L. quateirensis & 1 & $1335^{\mathrm{T}}$ & $\begin{array}{l}\text { L. pneumophila serogroup } 5 \text { strain Dallas } 1 \\
\text { L. pneumophila serogroup } 10 \text { strain Leiden } 1 \\
\text { L. worsleiensis serogroup } 1 \text { strain } 1347^{\mathrm{T}} \\
\text { L. pneumophila serogroup } 4 \text { strain Portland } 1 \\
\text { L. pneumophila serogroup } 8 \text { strain Concord } 3 \\
\text { L. pneumophila serogroup } 13 \text { strain } 82 \mathrm{~A} 3105 \\
\text { L. pneumophila serogroup } 14 \text { strain } 1169-\mathrm{MN}-\mathrm{H} \\
\text { L. pneumophila serogroup } 4 \text { strain Los Angeles } 1\end{array}$ & $\begin{array}{l}4+ \\
4+ \\
4+ \\
2+ \\
2+ \\
2+ \\
2+ \\
1+\end{array}$ \\
\hline
\end{tabular}

\footnotetext{
${ }^{a}$ Positive reactions were scored on a scale from $1+$ (barely visible) to $4+$ (strong agglutination).
} 
TABLE 4. Preparation of Legionella antisera for the SAT

\begin{tabular}{|c|c|c|c|c|c|}
\hline \multicolumn{3}{|c|}{ Immunizing antigen } & \multirow{2}{*}{ SAT titer ${ }^{a}$} & \multirow{2}{*}{ Antiserum } & \multirow{2}{*}{ Cross-reaction $^{b}$} \\
\hline Species & Serogroup & Strain & & & \\
\hline L. nautarum & 1 & $1224^{\mathrm{T}}$ & $1: 32$ & None & \\
\hline L. londiniensis & 1 & $1477^{\mathrm{T}}$ & $1: 16$ & None & \\
\hline L. geestiana & 1 & $1308^{\mathrm{T}}$ & $1: 8$ & None & \\
\hline L. worsleiensis & 1 & $1347^{\mathrm{T}}$ & $1: 16$ & $\begin{array}{l}\text { L. pneumophila serogroup } 4 \text { strain Portland } 1 \\
\text { L. quateirensis serogroup } 1 \\
\text {. }\end{array}$ & $\begin{array}{l}4+ \\
4+ \\
2+\end{array}$ \\
\hline L. quateirensis & 1 & $1335^{\mathrm{T}}$ & $1: 16$ & $\begin{array}{l}\text { L. pneumophila serogroup } 8 \\
\text { L. pneumophila serogroup } 4 \text { strain Los Angeles } 1 \\
\text { L. pneumophila serogroup } 10 \\
\text { L. pneumophila serogroup } 13 \\
\text { L. worsleiensis serogroup } 1 \\
\text { L. pneumophila serogroup } 4 \\
\text { L. pneumophila serogroup } 12\end{array}$ & $\begin{array}{l}2+ \\
4+ \\
4+ \\
4+ \\
4+ \\
2+ \\
1+\end{array}$ \\
\hline
\end{tabular}

${ }^{a}$ Highest dilution giving $4+$ agglutination.

${ }^{b}$ Intensities of cross-reactions observed by using working dilutions of antisera.

chain fatty acids, particularly 14-methylpentadecanoic acid (i16:0), 14-methylhexadecanoic acid (a17:0), and 12-methyltetradecanoic acid (a15:0). The fatty acid compositions of the five new species (Table 5) are thus consistent with those of other members of the genus (19).

The fatty acid profiles of $L$. quateirensis, L. nautarum, and $L$. worsleiensis are similar to each other and to the fatty acid profile of Legionella feeleii in that the proportion of unbranched acids (particularly 16:0, 16:1, and 18:0) is higher than this proportion in most Legionella species. The relative proportion of i16:0 and 16:1 was somewhat variable from experiment to experiment in these three organisms, a phenomenon which has also been observed in L. feeleii (21), where the fatty acid composition was shown to depend on the age of the culture. L. worsleiensis and L. quateirensis lack the cyclopropane ring-containing compound 9,10-methylenehexadecanoic acid (cyc-17).

L. londiniensis also lacks cyc-17 but is distinguishable from the other species because a17:0 is the predominant acid. L. geestiana differs from all previously described species by the presence of i15:0 and i17:0 in higher concentrations than their anteiso-branched isomers. 9,10-methylenehexadecanoic acid is again absent. There was also a peak not present in the other four species; this peak eluted before i17:0 and had a retention time similar to, but slightly shorter than, the retention time of a17:1 from Legionella micdadei. The mass spectrum of this constituent contained a molecular ion at $\mathrm{m} / \mathrm{z} 282$, suggesting that it was an unsaturated 17carbon acid. Signals at $m / z 227\left(\mathrm{M}-\mathrm{C}_{4} \mathrm{H}_{8}\right)^{+}, m / z 195$ (loss of $\mathrm{CH}_{3} \mathrm{OH}$ from $m / z 227$ ), and $m / z 177$ (dehydration product of $\mathrm{m} / z$ 195) define the structure as 15 -methylhexadecenoic acid (i17:1) (5). This acid is not usually encountered in other legionellae and is thus potentially useful for species discrimination.

Isoprenoid quinone composition. Isoprenoid quinones of the ubiquinone series containing more than 10 isoprene units in the side chain are highly characteristic of the Legionellaceae $(10,19)$. Ubiquinones were the sole respiratory quinones detected by reverse-phase high-performance thinlayer chromatography, reverse-phase HPLC, and negativeion fast atom bombardment mass spectrometry (37). The fast atom bombardment mass spectra were characterized by intense semiquinone molecular anion radicals $[\mathrm{M}]^{-}$, revealing the mass of each quinone molecular species present. A typical spectrum is shown in Fig. 1. The relative intensities of the molecular anions approximately reflect the concentrations of the individual quinones in the mixture and were in reasonable agreement with the results of the HPLC analysis (Table 6).

With the exception of the $L$. londiniensis profile, the quinone profiles were rather simple and were dominated by one or two major compounds. The quinone compositions of $L$. worsleiensis, $L$. quateirensis, and $L$. nautarum are qualitatively similar, containing mainly Q13 (60 to 80\%) and lesser amounts of Q12 and Q14. They thus somewhat resemble L. micdadei, Legionella jordanis, and L. jamestowniensis profiles $(19,36)$, although the former species differ from the latter species in fatty acid composition and other phenotypic characteristics. L. geestiana contains Q14 as its major quinone (approximately 50\%), as well as Q13 (>40\%); the remainder of the quinone complement consists of Q12 and Q15. This is rather similar to the $L$. feeleii profile, but again the fatty acid composition of $L$. geestiana makes confusion very unlikely. The quinone profile of $L$. londiniensis is

TABLE 5. Major nonhydroxylated fatty acids of the new Legionella species

\begin{tabular}{|c|c|c|c|c|c|c|c|c|c|c|c|c|c|c|c|}
\hline \multirow{2}{*}{ Strain } & \multicolumn{15}{|c|}{ Fatty acid composition ( $\%$ of total integrated area) ${ }^{a}$} \\
\hline & $\mathrm{i14:0}$ & $\mathrm{i} 15: 0$ & a15:0 & $15: 1$ & $15: 0$ & i16:1 & i16:0 & $16: 1$ & $16: 0$ & i17:1 & $\mathrm{i} 17: 0$ & a17:0 & cyc-17:0 & $17: 0$ & $18: 0$ \\
\hline L. worsleiensis $1347^{\mathrm{T}}$ & 4 & $\operatorname{tr}$ & 12 & 2 & 2 & 1 & 9 & 35 & 16 & 0 & 0 & 5 & 0 & 2 & 9 \\
\hline L. quateirensis $1335^{\mathrm{T}}$ & 3 & tr & 8 & 4 & 1 & $\operatorname{tr}$ & 20 & 35 & 7 & 0 & 0 & 4 & 0 & 3 & 10 \\
\hline L. londiniensis $1477^{\mathrm{T}}$ & $\operatorname{tr}$ & $\operatorname{tr}$ & 5 & 2 & 1 & $\mathrm{tr}$ & 11 & 19 & 15 & 0 & 0 & 23 & 0 & 8 & 8 \\
\hline L. nautarum $1224^{\mathrm{T}}$ & 2 & 0 & 19 & 2 & 2 & $\operatorname{tr}$ & 9 & 27 & 19 & 0 & 0 & 13 & 4 & 1 & 2 \\
\hline L. geestiana $1308^{\mathrm{T}}$ & $\operatorname{tr}$ & 16 & 9 & 1 & 1 & 0 & 2 & 20 & 18 & 2 & 9 & 7 & 0 & 1 & 4 \\
\hline
\end{tabular}

${ }^{a}$ Values are rounded off to the nearest whole percent. The total may not equal $100 \%$ because of rounding off and the omission of minor components. tr, trace $(<1 \%)$. 


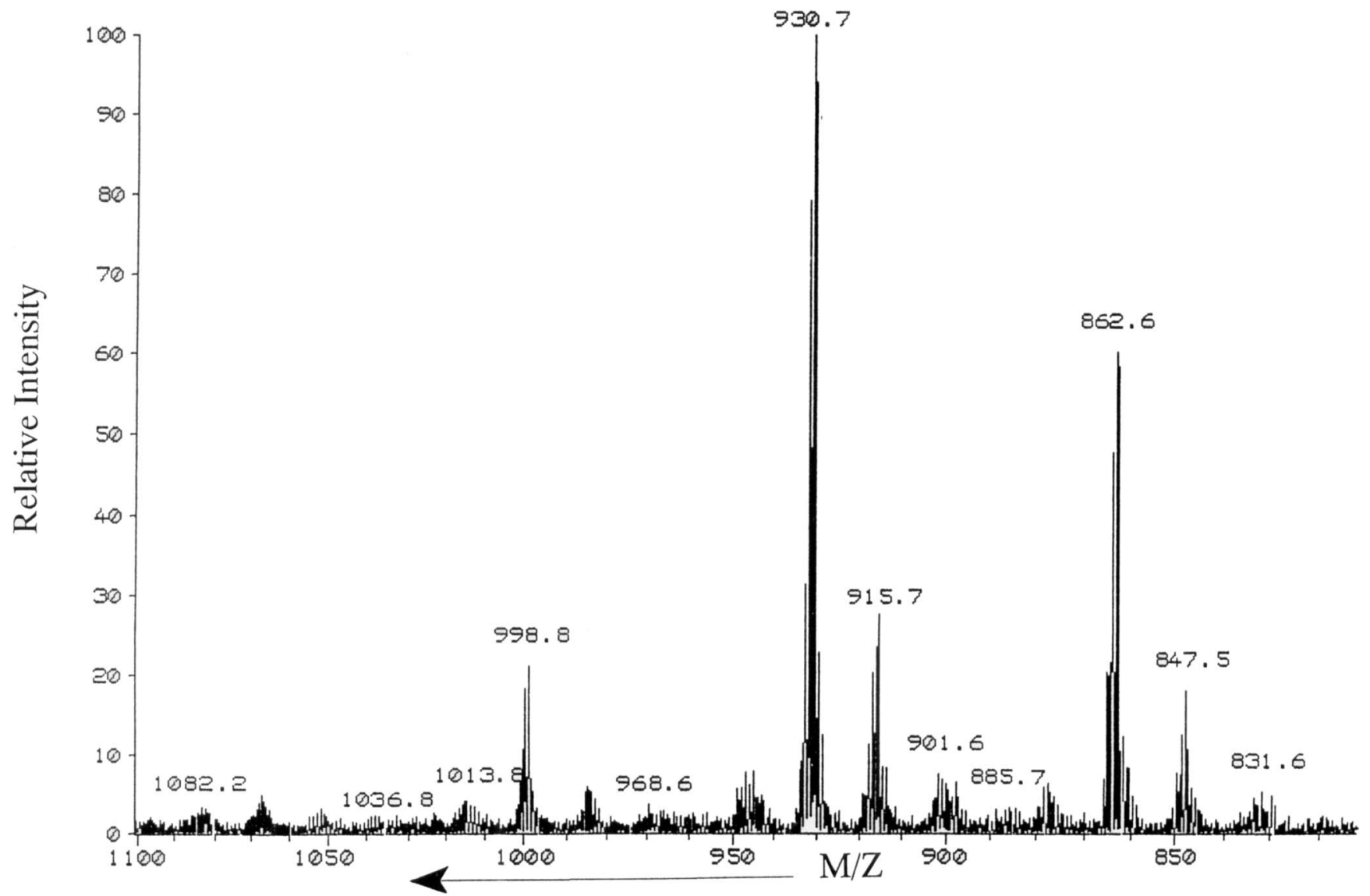

FIG. 1. Molecular ion region of the negative-ion fast atom bombardment mass spectrum of the ubiquinones of $L$. londiniensis 1466 . The signals at $\mathrm{m} / \mathrm{z} 862,930$, and 998 correspond to the molecular anions of Q10, Q11, and Q12, respectively. Each is accompanied by a fragment ion 15 a.m.u. lower in mass because of the elimination of a methyl group.

dominated by Q11 (approximately $60 \%$ of the total); Q10 and Q12 make up most of the balance (Fig. 1). L. londiniensis thus differs from the other four new species, and its quinone composition is also unlike any of the quinone compositions reported for 23 species by Lambert and Moss (19); it does however bear some resemblance to the quinone profile of the recently described species Legionella adelaidensis, which is also dominated by Q11 (1).

Biochemical tests. The biochemical characteristics of the five new species are shown in Table 7 and are detailed in the species descriptions below. $L$. quateirensis and $L$. worsleiensis, which are not serologically distinguishable, are separable biochemically, since L. quateirensis hydrolyzes

TABLE 6. Ubiquinone compositions of the five new species

\begin{tabular}{|c|c|c|c|c|c|c|c|}
\hline \multirow{2}{*}{ Strain } & \multicolumn{7}{|c|}{$\begin{array}{l}\text { Ubiquinone composition } \\
\text { (\% of total integrated area) }\end{array}$} \\
\hline & Q9 & Q10 & Q11 & Q12 & Q13 & Q14 & Q15 \\
\hline L. londiniensis 1466 & 2 & 24 & 55 & 16 & 2 & $\operatorname{tr}$ & ND \\
\hline L. worsleiensis $1347^{\mathrm{T}}$ & ND & 1 & 4 & 26 & 62 & 4 & tr \\
\hline L. quateirensis $1335^{\mathrm{T}}$ & ND & $\operatorname{tr}$ & 2 & 21 & 69 & 8 & $\operatorname{tr}$ \\
\hline L. nautarum $1224^{\mathrm{T}}$ & ND & $\mathrm{ND}$ & $\mathrm{ND}$ & 18 & 76 & 6 & ND \\
\hline L. geestiana $1308^{\mathrm{T}}$ & ND & ND & 1 & 4 & 39 & 52 & 2 \\
\hline
\end{tabular}

${ }^{a}$ The masses of the $[\mathrm{M}]^{-}$ions were as follows: Q10, 862; Q11, 930; Q12, 998; Q13, 1,066; and Q14, 1,134. tr, trace $(<1 \%)$; ND, not detected. starch and is positive for catalase, lipase, and protease activities, whereas $L$. worsleiensis is not.

\section{DISCUSSION}

Fourteen Legionella-like strains were shown to belong to the genus Legionella on the basis of growth characteristics, biochemical reactions, cell wall fatty acid and isoprenoid quinone compositions, and hybridization of their DNAs with a Legionella-specific gene probe. All strains required cysteine for growth and therefore grew on BCYE medium, but not on blood or Mueller-Hinton media. They were nonfermentative, lacked urease, and did not reduce nitrate. They contained predominantly branched-chain cell wall fatty acids and major amounts of ubiquinones with more than 10 isoprene units. Positive reactions with a DNA probe specific for the genus Legionella confirmed that these strains properly belong in the family Legionellaceae as presently constituted with the single genus Legionella.

These 14 strains formed five DNA relatedness groups that were less than $23 \%$ interrelated and showed $36 \%$ or lower levels of relatedness to previously described Legionella species. These data confirm that each of the DNA relatedness groups represents a new Legionella species. Three of the new species, $L$. geestiana, $L$. nautarum, and $L$. londiniensis, are serologically unique. $L$. worsleiensis and $L$. quateirensis cannot be serologically separated from each 
TABLE 7. Biochemical characteristics of the new Legionella species

\begin{tabular}{|c|c|c|c|c|c|}
\hline Reaction & L. worsleiensis & L. quateirensis & L. geestiana & L. londiniensis & L. nautarum \\
\hline Hippurate hydrolysis & $-{ }^{a}$ & - & $+{ }^{w}$ & - or $+^{w}$ & - \\
\hline D-Glucose (acid production) & - & - & - & - & - \\
\hline Catalase activity & - & + & + & $+w$ & + \\
\hline Oxidase activity & - & - & - & - & + \\
\hline Peroxidase activity & + & + & $t^{\mathrm{w}}$ & - & + \\
\hline Urease activity & - & - & - & - & - \\
\hline \multicolumn{6}{|c|}{ Browning with the following substrates: } \\
\hline Tyrosine & + & + & $+w$ & + & - \\
\hline 3,4-Diaminobenzoic acid & $+w$ & + & - & - & - \\
\hline 3,5-Diaminobenzoic acid & + & + & - & - & - \\
\hline Autofluorescence & - & - & - & - & - \\
\hline Bromocresol purple spot test & - & - & - & - & - \\
\hline$\beta$-Lactamase activity & + & + & - & + & + \\
\hline Elastase production & - & - & + & + & - \\
\hline Casein hydrolysis & + & + & + & $+w$ & - \\
\hline Albumin degradation & + & + & + & $+t^{w}$ & - \\
\hline Chondroitin sulfate degradation & + & + & + & - & - \\
\hline Starch hydrolysis & - & $+{ }^{w}$ & - & - & - \\
\hline DNase activity & + & + & + & + & - \\
\hline Gelatin hydrolysis & + & + & + & + & - \\
\hline Lipase activity & - & + & - & - & + \\
\hline Protease activity & - & + & - & - & - \\
\hline \multicolumn{6}{|l|}{ Alkaline phosphatase activity at: } \\
\hline $\mathrm{pH} 9.5$ & + & + & + & + & + \\
\hline pH 10.5 & + & + & + & + & + \\
\hline Single polar flagellum & + & + & + & - & - \\
\hline Requirement for cysteine & + & + & + & + & + \\
\hline \multicolumn{6}{|l|}{ Growth on: } \\
\hline Legionella blood agar & - & - & - & - & - \\
\hline Mueller-Hinton agar & - & - & - & - & - \\
\hline BCYE agar & + & + & + & + & + \\
\hline Nitrate reduction & - & - & - & - & - \\
\hline
\end{tabular}

${ }^{a}+$, positive; - , negative; $+^{\mathrm{w}}$, weakly positive.

other, but may be distinguished by their biochemical reactions (Table 7). L. worsleiensis and L. pneumophila serogroup 4 are likewise serologically indistinguishable but may be differentiated by their fatty acid profiles and biochemically, since $L$. pneumophila serogroup 4 is positive for hippurate and starch hydrolysis and negative for browning on 3,4- and 3,5-diaminobenzoic acids (33), whereas the converse is true of $L$. worsleiensis (Table 7).

Taxonomic proposals. Nomenclatural proposals are given below for five new species of the genus Legionella that conform to the definitions of the family Legionellaceae and the genus Legionella $(8,10)$. All of the species are gramnegative rods that require cysteine for growth and grow on BCYE agar but not on blood agar or Mueller-Hinton agar. They are not autofluorescent and do not reduce nitrate, contain a urease, or produce acid from $\mathrm{D}$-glucose. They exhibit alkaline phosphatase activity at $\mathrm{pH} 9.5$ and 10.5 and are negative for the bromocresol purple spot test. The sources of the strains of the species are given in Table 1 , and their DNA relatedness relationships are shown in Table 2. Tables 5 through 7 summarize their fatty acid profiles, quinone compositions and biochemical reactions. Their serological reactions are listed in Tables 3 and 4 . Other characteristics are given above and below.

Legionella geestiana sp. nov. Legionella geestiana (gees. ti. a' na. N.L. adj. geestiana, pertaining to the Geest office building) is an oxidase-negative, catalase-positive organism with a single polar flagellum. It reacts positively in tests for hippurate hydrolysis, peroxidase activity, browning on agar containing tyrosine, elastase production, casein hydrolysis, albumin degradation, chondroitin sulfate degradation, DNase activity, and gelatin hydrolysis. It gives negative results in tests for browning on agar containing 3,4- and 3,5-diaminobenzoic acid, $\beta$-lactamase activity, starch hydrolysis, lipase activity, and protease activity. The type strain is strain 1308 (= ATCC 49504), which has a G+C content of $52 \mathrm{~mol} \%$.

Legionella nautarum sp. nov. Legionella nautarum (nau. tar' um. N.L. gen. n. nautarum, of sailors) is a nonmotile oxidase- and catalase-positive organism. It exhibits positive reactions in tests for peroxidase, $\beta$-lactamase, and lipase activities. It gives negative results in tests for hippurate hydrolysis, elastase production, casein hydrolysis, albumin degradation, chondroitin sulfate degradation, starch hydrolysis, DNase activity, gelatin hydrolysis, protease activity, and browning on agar containing tyrosine, 3,4-diaminobenzoic acid, and 3,5-diaminobenzoic acid. The type strain is strain 1224 (= ATCC 49506), which has G+C content of 41 mol\%.

Legionella londiniensis sp. nov. Legionella londiniensis (lon. din. i. en' sis. N.L. gen. n. londiniensis, coming from London) is a nonmotile, oxidase-negative, catalase-positive organism. It gives positive reactions in tests for browning on agar containing tyrosine, $\beta$-lactamase activity, elastase production, and casein hydrolysis. It exhibits negative reactions in tests for hippurate hydrolysis (sometimes weakly positive), peroxidase activity, browning on agar containing 3,4or 3,5-diaminobenzoic acid, chondroitin sulfate degradation, starch hydrolysis, lipase activity, and protease activity. The 
type strain is strain 1477 (= ATCC 49505), which has a G+C content of $43 \mathrm{~mol} \%$.

Legionella quateirensis sp. nov. Legionella quateirensis (qua. teir. en' sis. N.L. gen. n. quateirensis, coming from Quarteira) is an oxidase-negative, catalase-positive organism with a single polar flagellum. It gives positive results in tests for peroxidase activity, browning on agar containing tyrosine or 3,4- or 3,5-diaminobenzoic acid, $\beta$-lactamase activity, casein hydrolysis, albumin degradation, chondroitin sulfate degradation, starch hydrolysis, DNase activity, gelatin hydrolysis, lipase activity, and protease activity. It gives negative reactions in tests for hippurate hydrolysis and elastase production. The type strain is strain 1335 (= ATCC 49507), which has a $\mathrm{G}+\mathrm{C}$ content of $39 \mathrm{~mol} \%$.

Legionella worsleiensis sp. nov. Legionella worsleiensis (wors. lei. en' sis. N.L. gen. n. worsleiensis, coming from Worsley) is an oxidase- and catalase-negative organism with a single polar flagellum. It gives positive reactions in tests for peroxidase activity, browning on agar containing tyrosine or 3,4- or 3,5-diaminobenzoic acid, $\beta$-lactamase activity, casein hydrolysis, albumin degradation, chondroitin sulfate degradation, DNase activity, and gelatin hydrolysis. It gives negative reactions in tests for hippurate hydrolysis, elastase production, starch hydrolysis, lipase activity, and protease activity. The type strain is strain 1347 (= ATCC 49508), which has a $\mathrm{G}+\mathrm{C}$ content of $41 \mathrm{~mol} \%$.

\section{ACKNOWLEDGMENTS}

We are grateful to Thomas Ozro MacAdoo (Associate Professor Emeritus of Greek and Latin, Virginia Polytechnic Institute and University, Blacksburg) for his expert advice on latinization of the species names. We thank Michael Hudson, Aileen West, and Tim Harrison for their various contributions; Wendy Brown and Bruce Jones for assistance with the practical work; and John V. Lee for his help and generous advice.

\section{REFERENCES}

1. Benson, R. F., W. L. Thacker, J. A. Lanser, N. Sangster, W. R. Mayberry, and D. J. Brenner. 1991. Legionella adelaidensis, a new species isolated from cooling tower water. J. Clin. Microbiol. 29:1004-1006.

2. Benson, R. F., W. L. Thacker, R. P. Walters, P. A. Quinlivan, W. R. Mayberry, D. J. Brenner, and H. W. Wilkinson. 1989. Legionella quinlivanii sp. nov. isolated from water. Curr. Microbiol. 18:195-197.

3. Bercovier, H., A. G. Steigerwalt, M. Derhi-Cochin, C. W. Moss, H. W. Wilkinson, R. F. Benson, and D. J. Brenner. 1986. Isolation of legionellae from oxidation ponds and fishponds in Israel and description of Legionella israelensis sp. nov. Int. J. Syst. Bacteriol. 36:368-371.

4. Birtles, R. J., N. Doshi, N. A. Saunders, and T. G. Harrison. 1991. Second serogroup of Legionella quinlivanii isolated from two unrelated sources in the United Kingdom. J. Appl. Bacteriol. 71:402-406.

5. Boon, J. J., B. van de Graaf, P. J. W. Schuyl, F. de Lange, and J. W. de Leeuw. 1977. The mass spectra of iso and anteiso monoenoic fatty acids. Lipids 12:717-721.

6. Bopp, C. A., J. W. Sumner, G. K. Morris, and J. G. Wells. 1981. Isolation of Legionella spp. from environmental water samples by low-pH treatment and use of a selective medium. J. Clin. Microbiol. 13:714-719.

7. Bornstein, N., D. Marmet, M. Surgot, M. Nowicki, H. Meugnier, J. Fleurette, E. Ageron, F. Grimont, P. A. D. Grimont, W. L. Thacker, R. F. Benson, and D. J. Brenner. 1989. Legionella gratiana $\mathrm{sp}$. nov. isolated from French spa water. Res. Microbiol. 140:541-542.

8. Brenner, D. J., J. C. Feeley, and R. E. Weaver. 1984. Family VII. Legionellaceae Brenner, Steigerwalt, and McDade 1979, 658 , p. 279-288. In N. R. Kreig and J. G. Holt (ed.), Bergey's manual of systematic bacteriology, vol. 1. The Williams and Wilkins Co., Baltimore.

9. Brenner, D. J., A. C. McWhorter, J. K. Leete-Knutson, and A. G. Steigerwalt. 1982. Escherichia vulneris: a new species of Enterobacteriaceae associated with human wounds. J. Clin. Microbiol. 15:1133-1140.

10. Brenner, D. J., A. G. Steigerwalt, G. W. Gorman, H. W. Wilkinson, W. F. Bibb, M. Hackél, R. L. Tyndall, J. Campbell, J. C. Feeley, W. L. Thacker, P. Skaliy, W. T. Martin, B. J. Brake, B. S. Fields, H. V. McEachern, and L. K. Corcoran. 1985. Ten new species of Legionella. Int. J. Syst. Bacteriol. 35:50-59.

11. Brenner, D. J., A. G. Steigerwalt, and J. E. McDade. 1979. Classification of the Legionnaires' disease bacterium: Legionella pneumophila, genus novum, species nova, of the family Legionellaceae, familia nova. Ann. Intern. Med. 90:656-658.

12. Collins, M. D., T. Pirouz, M. Goodfellow, and D. E. Minnikin. 1977. Distribution of menaquinones in actinomycetes and corynebacteria. J. Gen. Microbiol. 51:129-134.

13. Dennis, P. J. L. 1988. Isolation of Legionella from environmental specimens, p. 31-34. In T. G. Harrison and A. G. Tayler (ed.), A laboratory manual for Legionella. Wiley, Chichester, United Kingdom.

14. Dennis, P. J. L., J. A. Taylor, and G. I. Barrow. 1981. Phosphate buffered, low sodium chloride blood agar for Legionella pneumophila. Lancet ii:636.

15. Garrity, G. M., A. Brown, and R. M. Vickers. 1980. Tatlockia and Fluoribacter: two new genera of organisms resembling Legionella pneumophila. Int. J. Syst. Bacteriol. 30:609-614.

16. Hébert, G. A. 1981. Hippurate hydrolysis by Legionella pneumophila. J. Clin. Microbiol. 13:240-242.

17. Holmes, R. L. 1982. Aniline blue-containing BCYE medium for presumptive identification of Legionella species. J. Clin. Microbiol. 15:723-724.

18. Kohne, D. E., A. G. Steigerwalt, and D. J. Brenner. 1984. Nucleic acid probe specific for members of the genus $L e$ gionella, p. 107-108. In C. Thornsberry, A. Balows, J. C. Feeley, and W. Jakubowski (ed.), Legionella. Proceedings of the Second International Symposium. American Society for Microbiology, Washington, D.C.

19. Lambert, M. A., and C. W. Moss. 1989. Cellular fatty acid compositions and isoprenoid quinone contents of 23 Legionella species. J. Clin. Microbiol. 27:465-473.

20. Marmur, J., and P. Doty. 1962. Determination of the base composition of deoxyribonucleic acid from its thermal denaturation temperature. J. Mol. Biol. 5:109-118.

21. Moss, C. W., W. F. Bibb, D. E. Carr, G. O. Guerrant, and M. A. Lambert. 1983. Cellular fatty acid composition and ubiquinone content of Legionella feeleii sp. nov. J. Clin. Microbiol. 18:917919.

22. Orrison, L. H., W. B. Cherry, R. L. Tyndall, C. B. Fliermans, S. B. Gough, M. A. Lambert, W. F. Bibb, L. K. McDougal, and D. J. Brenner. 1983. Legionella oakridgensis: unusual new species isolated from cooling tower water. Appl. Environ. Microbiol. 45:536-545.

23. Pine, L., P. S. Hoffman, G. B. Malcolm, R. F. Benson, and G. W. Gorman. 1984. Whole-cell peroxidase test for identification of Legionella pneumophila. J. Clin. Microbiol. 19:286-290.

24. Preston, N. W., and A. Morrell. 1962. Reproducible results with the Gram stain. J. Pathol. Bacteriol. 84:241-243.

25. Ristroph, J. D., K. W. Hedlund, and R. G. Allen. 1980. Liquid medium for growth of Legionella pneumophila. J. Clin. Microbiol. 11:19-21.

26. Saunders, N. A., N. Doshi, and T. G. Harrison. 1992. A second serogroup of Legionella erythra serologically indistinguishable from Legionella rubrilucens. J. Appl. Bacteriol. 71:262-265.

27. Thacker, W. L., R. F. Benson, L. Hawes, H. Gidding, B. Dwyer, W. R. Mayberry, and D. J. Brenner. 1991. Legionella fairfieldensis sp. nov. isolated from cooling tower waters in Australia. J. Clin. Microbiol. 29:475-478.

28. Thacker, W. L., R. F. Benson, R. B. Schifman, E. Pugh, A. G. Steigerwalt, W. R. Mayberry, D. J. Brenner, and H. W. Wilkinson. 1989. Legionella tucsonensis sp. nov. isolated from a renal transplant recipient. J. Clin. Microbiol. 27:1831-1834. 
29. Thacker, W. L., R. F. Benson, J. L. Staneck, S. R. Vincent, W. R. Mayberry, D. J. Brenner, and H. W. Wilkinson. 1988. Legionella cincinnatiensis sp. nov. isolated from a patient with pneumonia. J. Clin. Microbiol. 26:418-420.

30. Thacker, W. L., J. W. Dyke, R. F. Benson, D. H. Havlichek, Jr., B. Robinson-Dunn, H. Stiefel, W. Schneider, C. W. Moss, W. R. Mayberry, and D. J. Brenner. 1992. Legionella lansingensis sp. nov. isolated from a patient with pneumonia and underlying chronic lymphocytic leukemia. J. Clin. Microbiol. 30:23982401.

31. Thacker, W. L., B. B. Plikaytis, and H. W. Wilkinson. 1985. Identification of 22 Legionella species and 33 serogroups with the slide agglutination test. J. Clin. Microbiol. 21:779-782.

32. Verma, U. K., D. J. Brenner, W. L. Thacker, R. F. Benson, G. Vesey, J. B. Kurtz, P. J. L. Dennis, A. G. Steigerwalt, J. S. Robinson, and C. W. Moss. 1992. Legionella shakespearei sp. nov., isolated from cooling tower water. Int. J. Syst. Bacteriol. 42:404-407.

33. Vesey, G., P. J. Dennis, J. V. Lee, and A. A. West. 1988. Further development of simple tests to differentiate the legionellas. J. Appl. Bacteriol. 65:339-345.

34. Vickers, R. M., A. Brown, and G. M. Garrity. 1981. Dyecontaining buffered charcoal yeast extract medium for differentiation of members of the family Legionellaceae. J. Clin. Microbiol. 13:380-382.

35. Vickers, R. M., and V. L. Yu. 1984. Clinical laboratory differentiation of Legionellaceae family members with pigment pro- duction and fluorescence on media supplemented with aromatic substrates. J. Clin. Microbiol. 19:583-587.

36. Wait, R. 1988. Confirmation of the identity of legionellae by whole cell fatty-acid and isoprenoid quinone profiles, p. 69-101. In T. G. Harrison and A. G. Taylor (ed.), A laboratory manual for Legionella. Wiley, Chichester, United Kingdom.

37. Wait, R. 1992. The use of FAB MS of cellular lipids for the characterization of medically important bacteria, p. 427-441. In M. L. Gross (ed.), Mass spectrometry in the biological sciences: a tutorial. Kluwer Academic Publishers, Dordrecht, The Netherlands.

38. Weaver, R. E., and J. C. Feeley. 1979. Cultural and biochemical characterization of the legionnaires' disease bacterium, p. 20 25. In G. L. Jones and G. A. Hébert (ed.), Legionnaires': the disease, the bacterium and methodology. Centers for Disease Control, Atlanta.

39. Wilkinson, H. W., V. Drasar, W. L. Thacker, R. F. Benson, J. Schindler, B. Potuznikova, W. R. Mayberry, and D. J. Brenner. 1988. Legionella moravica sp. nov. and Legionella brunensis sp. nov. isolated from cooling tower water. Ann. Inst. Pasteur Microbiol. 139:393-402.

40. Wilkinson, H. W., W. L. Thacker, R. F. Benson, S. S. Polt, E. Brookings, W. R. Mayberry, D. J. Brenner, R. G. Gilley, and J. K. Kirklin. 1987. Legionella birminghamensis sp. nov. isolated from a cardiac transplant recipient. J. Clin. Microbiol. 25:2120-2122. 